\title{
ANALISIS PENGARUH STRUKTUR PASAR DAN PERILAKU PASAR TERHADAP KINERJA PASAR PADA BANK UMUM SYARIAH DI INDONESIA DAN MALAYSIA TAHUN 2011-2015[1]
}

\author{
Rachma Revida \\ Mahasiswa Program Studi S1 Ekonomi Islam-Fakultas Ekonomi dan Bisnis-Universitas Airlangga \\ Email : rachma.revida-12@feb.unair.ac.id
}

Dina Fitrisia Septiarini

Dosen Departemen Ekonomi Syariah-Fakultas Ekonomi dan Bisnis-Universitas Airlangga

Email : dina.fitrisia@feb.unair.ac.id

\begin{abstract}
:
The aim of this study was to analyze the influence of market concentration, market share, and OEOR on profitability in Islamic Banks in Indonesia and Malaysia in 2011 - 2015 using the paradigm of structure, conduct, and performance. The samples of the study consisted of a total 11 Islamic banks in Indonesia and 16 Islamic banks in Malaysia. The analysis technique use in this study was panel data regression using Eviews 7.0 programme. The independence variables of the study were market concentration ratio HerfindahlHirchman index), market share, and OEOR, while the dependent variable was the return of asset (ROA). The results of this study indicate that market concentration and market share variables not significantly affect the ROA of Islamic banks in Indonesia and Malaysia, while the OEOR variable has significant effect to the ROA of Islamic banks in Indonesia and Malaysia.
\end{abstract}

Keywords: Market Structure, Market Conduct, Market Performance, SCP.

\section{PENDAHULUAN} Latar Belakang

Perkembangan perbankan syariah di Indonesia diawali dengan berdirinya Bank Muamalat Indonesia pada tahun 1991 (Karim, 2015:25). Sedangkan menurut Antonio (2001:24) menyatakan bahwa di Malaysia bank syariah sudah ada pada tahun 1983 dimana Bank Islam Malaysia Berhad (BIMB) menjadi bank syariah pertama di Malaysia.

Rata-rata pertumbuhan aset bank umum syariah di Indonesia sebesar 22,48\%, sedangkan rata-rata pertumbuhan aset bank umum syariah di Malaysia yaitu sebesar 12,91\%. Artinya, rata-rata pertumbuhan aset bank umum syariah di Indonesia secara presentase lebih besar bila dibandingkan dengan rata-rata pertumbuhan aset bank umum syariah di Malaysia. Hal ini membuktikan walaupun perkembangan bank syariah di Indonesia sedikit terlambat bila dibandingkan dengan Malaysia, namun Indonesia diproyeksikan dapat melangkah lebih jauh dalam industri perbankan syariah beberapa tahun ke depan.

Jika diteliti lebih jauh, perkembangan aset yang semakin meningkat tidak terlepas dari kinerja bank yang dipengaruhi oleh struktur pasar, perilaku pasar maupun proksi lain dari kinerja pasar. Penilaian terhadap kinerja perbankan dapat dilihat dengan paradigma Structure, Conduct, and Performance (SCP). Menurut Teguh (2010:22), menyatakan bahwa paradigma ini memperlihatkan hubungan keterkaitan antara struktur pasar (market structure), perilaku pasar (market conduct), dan kinerja pasar (market performance).

1) Jurnal Ini merupakan bagian dari Skripsi yang ditulis oleh Rachma Revida; NIM:041211433011 yang diuji pada tanggal 11 Agustus 2016 
Revida, et al/Jurnal Ekonomi Syariah Teori dan Terapan Vol. 4 No. 5 Mei 2017: 367-380; ANALISIS PENGARUH STRUKTUR PASAR DAN PERILAKU PASAR TERHADAP KINERJA PASAR PADA BANK UMUM SYARIAH DI INDONESIA DAN MALAYSIA TAHUN 2011-2015

Terdapat fenomena gap yaitu nilai kosentrasi pasar bank umum syariah di Indonesia yang dihitung dengan menggunakan Indeks HerfindahlHirschman (IHH) sebesar 21,07\%, yang mana hasil tersebut menunjukkan bahwa struktur pasar bank umum syariah di Indonesia cenderung bersifat oligopoli. Hal tersebut dibuktikan dengan $82,18 \%$ pangsa pasar bank umum syariah di Indonesia dipegang oleh empat bank yang memiliki total pembiayaan di atas Rp 10 Triliyun.

Sedangkan fenomena gap yang terdapat pada bank umum syariah di Malaysia yaitu nilai kosentrasi pasar yang dihitung dengan menggunakan Indeks Herfindahl-Hirschman (IHH)sebesar 15,99 persen, yang mana hasil tersebut menunjukkan bahwa struktur pasar bank umum syariah di Malaysia juga cenderung bersifat oligopoli. Hal tersebut dibuktikan dengan 87,95 persen pangsa pasar bank umum syariah di Malaysia dipegang oleh sembilan bank yang memiliki total pembiayaan diatas RM 10 Miliyar.

Dalam penelitian ini paradigma SCP menggunakan rasio kosentrasi yang diukur dengan Indeks HerfindahlHirschman dan pangsa pasar sebagai variabel yang menjadi proksi dari struktur pasar dan derajat kompetisi dalam industri. Kemudian menggunakan rasio Biaya Operasional terhadap Pendapatan Operasional (BOPO) sebagai variabel yang menjadi proksidari perilaku perusahaan yang dapat mempengaruhi kinerja perusahaan. Sedangkan untuk mengukur kinerja sebuah perusahaan penelitian ini menggunakan profitabitas. Ukuran profitabilitas salah satunya dapat dilihat melalui tingkat Return on Assets (ROA).

Telah banyak penelitian yang dilakukan dengan menggunakan paradigma Structure, Conduct, and Performance (SCP) untuk industri perbankan. Salah satunya adalah penelitian yang dilakukan Michael Smirlock (1985) dalam Amalia dan Nasution (2007) yang berjudul Evidence of The (Non) Relationship between Concentration and Bank Profitability, menemukan bahwa konsentrasi tidak mempengaruhi profitabilitas dalam industri perbankan. Hal ini tentu saja berbeda dengan hasil analisa SCP untuk industri lain pada umumnya dimana peningkatan konsentrasi akan meningkatkan profitabilitas perusahaan.

Berdasarkan penjelasan tersebut, maka rumusan masalah dalam penelitian ini adalah:

1. Apakah rasio kosentrasi pasar memiliki pengaruh terhadap Profitabilitas BUS di Indonesia tahun 2011-2015?

2. Apakah pangsa pasar memiliki pengaruh terhadap Profitabilitas BUS di Indonesia tahun 2011-2015?

3. Apakah Biaya Operasional terhadap Pendapatan Operasional (BOPO) memiliki pengaruh terhadap profitabilitas BUS di Indonesia tahun 2011-2015? 
Revida, et al/Jurnal Ekonomi Syariah Teori dan Terapan Vol. 4 No. 5 Mei 2017: 367-380; ANALISIS PENGARUH STRUKTUR PASAR DAN PERILAKU PASAR TERHADAP KINERJA PASAR PADA BANK UMUM SYARIAH DI INDONESIA DAN MALAYSIA TAHUN 2011-2015

4. Apakah rasio kosentrasi pasar memiliki pengaruh terhadap Profitabilitas BUS di Malaysia tahun 2011-2015?

5. Apakah pangsa pasar memiliki pengaruh terhadap Profitabilitas BUS di Malaysia tahun 2011-2015?

6. Apakah yaitu Biaya Operasional terhadap Pendapatan Operasional (BOPO) memiliki pengaruh terhadap profitabilitas BUS di Malaysia tahun 2011-2015?

Adapun tujuan dari penelitian ini adalah untuk mengetahui bagaimana pengaruh rasio kosentrasi pasar, pangsa pasar dan BOPO terhadap profitabilitas bank umum syariah yang ada di Indonesia dan Malaysia tahun 2011-2015.

\section{LANDASAN \\ TEORI \\ PENGEMBANGAN HIPOTESIS}

DAN

Menurut Burgess (1988) dalam Murthy dan Deb (2008), hubungan antara Structure, Conduct, and Performance sangat dipengaruhi oleh kondisi dasar masing-masing perusahaan. Variabel kondisi dasar dapat meliputi: sejarah, hukum atau perundang-undangan, teknologi, serta elastisitas permintaan dan penawaran. Kemudian variabel struktur, meliputi: variabel konsentrasi, skala ekonomi, hambatan masuk, dan diferensiasi produk. Variabel yang terdapat pada perilaku, meliputi: branch network, spread, NPA, Metro Branches, Staff, Diversification, Advertising, Financing, Merger, dan Pengeluaran Operasional. Sedangkan variabel yang terdapat dalam kinerja, meliputi: ROA, ROE, stabilitas, profitabilitas per cabang, produktivitas per cabang, allocative efficiency, technical efficiency, dan $X$ efficiency.

Di dalam penelitian ini, structure merupakan bagian dari struktur pasar yang biasanya didefenisikan oleh rasio kosentrasi pasar dan pangsa pasar. Secara umum keadaan struktur pasar suatu industri dapat dikelompokkan ke dalam dua bagian besar, yaitu struktur pasar persaingan sempurna dan struktur pasar persaingan tidak sempurna. Selanjutnya, struktur pasar persaingan tidak sempurna dapat terdiri dari struktur pasar persaingan monopolistik, oligopoli dan monopoli (Teguh, 2010:29).

Conduct merupakan tindakan atau perilaku yang dijalankan oleh setiap perusahaan industri. Menurut Joe S. Bain (1940) dalam Tallattov dan Sugiyanto (2011), mengatakan bahwa perilaku pasar hanya merupakan cerminan dari sifat bersaing pada suatu pasar. Variabel yang dapat memproyeksikan perilaku perusahaan yaitu rasio Biaya Operasional Terhadap Pendapatan Operasional. BOPO merupakan rasio rentabilitas, yang mana variabel ini mencerminkan perilaku perusahaan dalam mendapatkan keuntungan.

Sedangkan performance atau kinerja merupakan hasil-hasil atau prestasi yang muncul di dalam pasar sebagai reaksi telah terjadinya persaingan antar perusahaan(Teguh, 2010:20). Kinerja pasar dapat muncul dalam berbagai bentuk, salah satunya adalah profitabilitas. Salah 
Revida, et al/Jurnal Ekonomi Syariah Teori dan Terapan Vol. 4 No. 5 Mei 2017: 367-380; ANALISIS PENGARUH STRUKTUR PASAR DAN PERILAKU PASAR TERHADAP KINERJA PASAR PADA BANK UMUM SYARIAH DI INDONESIA DAN MALAYSIA TAHUN 2011-2015

satu rasio keuangan yang menjadi ukuran profitabilitas yaitu Return on Assets (ROA). Joe S. Bain (1940) dalam llusmawati dan Nuswantara (2014) mengartikan konsentrasi sebagai kepemilikan terhadap sejumlah besar sumber daya ekonomi oleh sejumlah kecil pelaku ekonomi. Tingkat konsentrasi merupakan indikator dari struktur pasar. Apabila tingkat konsentrasi dalam suatu industri tinggi, maka tingkat persaingan antar perusahaan dalam industri tersebut rendah. konsentrasi pasar yang semakin besar menyebabkan biaya untuk melakukan kolusi menjadi rendah sehingga perusahaan dalam industri tersebut akan mendapatkan laba supernormal. Dengan demikian dapat diasumsikan bahwa setiap perubahan yang terjadi pada kosentrasi pasar akan menyebabkan perubahan terhadap ROA.

Purnama dan Setiawan (2003) dalam llusmawati dan Nuswantara (2014):

"Pangsa pasar merupakan pengukuran kinerja yang dapat membedakan pemenang dan pecundang karena pangsa pasar yang tinggi menunjukkan perusahaan lebih unggul dalam bersaing daripada pesaing dalam suatu industri"

Bank yang memiliki pangsa pasar pembiayaan yang tinggi, menujukkan bank tersebut memiliki keunggulan kompetitif. Bank yang memiliki pangsa pasar lebih besar daripada pesaing akan mendapatkan keuntungan dari peningkatan permintaan pembiayaan. Peningkatan permintaan pembiayaan dapat meningkatkan profitabilitas bank, karena bank akan mendapatkan pendapatan dari hasil pembiayaan lebih banyak. Dengan demikian dapat diasumsikan bahwa setiap perubahan yang terjadi pada pangsa pasar akan menyebabkan perubahan terhadap ROA. Rasio Biaya Operasional atas Pendapatan Operasional (BOPO) sering disebut rasio efisiensi yang digunakan untuk mengukur kemampuan manajemen bank dalam mengendalikan biaya operasional terhadap pendapatan operasional. Bank Indonesia menetapkan angka terbaik untuk rasio BOPO adalah di bawah 90\%, jika rasio BOPO melebihi $90 \%$ maka bank tersebut dapat dikategorikan tidak efisien dalam menjalankan operasinya (Prasetyo dan Sunaryo, 2015). Semakin kecil BOPO menunjukan semakin efisien bank tersebut dalam menjalankan aktivitas usahanya sehingga ROA akan semakin besar (llusmawati dan Nuswantara, 2014). Dengan demikian dapat diasumsikan bahwa setiap perubahan yang terjadi pada BOPO akan menyebabkan perubahan terhadap ROA. Berdasarkan pada rumusan masalah, tujuan dan landasan teori yang telah dijelaskan sebelumnya, maka hipotesis dari penelitian ini adalah sebagai berikut:

$\mathrm{H}_{1}$ : Variabel rasio kosentrasi pasar berpengaruh secara signifikan terhadap profitabilitas pada BUS di Indonesia tahun 2011-2015.

$\mathrm{H}_{2}$ : Variabel pangsa pasar berpengaruh secara signifikan terhadap profitabilitas pada BUS di Indonesia tahun 2011-2015. 
Revida, et al/Jurnal Ekonomi Syariah Teori dan Terapan Vol. 4 No. 5 Mei 2017: 367-380; ANALISIS PENGARUH STRUKTUR PASAR DAN PERILAKU PASAR TERHADAP KINERJA PASAR PADA BANK UMUM SYARIAH DI INDONESIA DAN MALAYSIA TAHUN 2011-2015

$\mathrm{H}_{3}$ : Variabel $\mathrm{BOPO}$ berpengaruh secara signifikan terhadap profitabilitas pada BUS di Indonesia tahun 2011-2015.

$\mathrm{H}_{4}$ : Variabel rasio kosentrasi pasar berpengaruh secara signifikan terhadap profitabilitas pada BUS di Malaysia tahun 2011-2015.

$\mathrm{H}_{5}$ : Variabel pangsa pasar berpengaruh secara signifikan terhadap profitabilitas pada BUS di Malaysia tahun 2011-2015.

$\mathrm{H}_{6}$ : Variabel BOPO berpengaruh secara signifikan terhadap profitabilitas pada BUS di Malaysia tahun 2011-2015.

Model analisis pada penelitian ini dapat dilihat pada gambar 1 dimana penelitian menggunakan analisis regresi data panel.

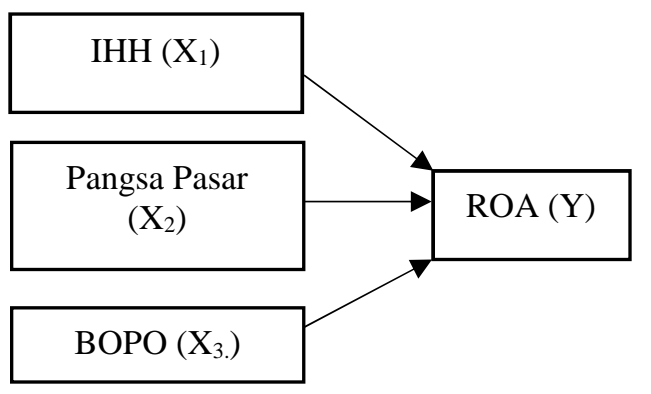

Gambar 1.

Model Analisis Pengaruh Kosentrasi Pasar,

Pangsa Pasar, dan BOPO Terhadap

Profitabilitas Pada BUS di Indonesia dan

$$
\text { Malaysia }
$$

\section{METODE PENELITIAN}

\section{Pendekatan Penelitian}

Pendekatan yang digunakan dalam penelitiaan ini adalah pendekatan kuantitatif dengan metode regresi linear data panel yang diolah dengan menggunakan softwareEviews 7.

\section{Variabel Independen:}

1. Indeks Herfindahl-Hirschman ( $\left.X_{1}\right)$
Indeks Herfindahl Hirschman merupakan penjumlahan kuadran pangsa pasar semua perusahan dalam suatu industri (nay, 2001:64). Hasil penghitungan $\mathrm{IHH}$ berupa presentase. Data ini diperoleh melalui annual report, laporan keuangan secara tahunan dari masing-masing BUS di Indonesia dan Malaysia tahun 2011-2015.

2. Pangsa Pasar $\left(X_{2}\right)$

Pangsa pasar atau market share merupakan besarnya bagian pasar yang dikuasai oleh suatu perusahaan. Menurut Tallatov dan Sugiyanto, (2011) pangsa pasar dihitung dengan memerhitungkan total pembiayaan yang dimiliki oleh sebuah bank relatif terhadap total pembiayaan seluruh bank dalam industri. Hasil penghitungan pangsa pasar berupa presentase. Data pangsa pasar diperoleh melalui melalui annual report, laporan kevangan secara tahunanmasing-masing BUS di Indonesia dan Malaysia tahun 20112015.

3. Beban Operasional terhadap Pendapatan Operasional $\left(X_{3}\right)$

Dalam penelitian ini BOPO menjadi variabel perilaku, yang mana variabel ini merupakan perilaku perusahaan yang dapat mempengaruhi kinerja perusahaan. Rasio Biaya Operasional atas Pendapatan Operasional (BOPO) dihitung dengan membagi biaya operasional terhadap pendapatan operasional yang dimiliki perusahaan. Hasil penghitungan BOPO berupa presentase. Data ini diperoleh melalui melalui melalui annual report, laporan kevangan secara 
Revida, et al/Jurnal Ekonomi Syariah Teori dan Terapan Vol. 4 No. 5 Mei 2017: 367-380; ANALISIS PENGARUH STRUKTUR PASAR DAN PERILAKU PASAR TERHADAP KINERJA PASAR PADA BANK UMUM SYARIAH DI INDONESIA DAN MALAYSIA TAHUN 201 1-2015

tahunanmasing-masing BUS di Indonesia dan Malaysia dari tahun 2011-2015.

\section{Variabel Dependen:}

1. Return on Asset (Y)

$$
\text { Menurut Surat Edaran Bank }
$$
Indonesia Nomor 9/24/DPbs tahun 2007, tujuan dari rasio ROA adalah untuk mengukur keberhasilan manajemen dalam menghasilkann laba. Hasil penghitungan ROA berupa presentase. Data ini diperoleh melalui melalui melalui annual report, laporan kevangan secara tahunan darimasing-masing BUS di Indonesia dan Malaysia tahun 2011-2015.

\section{Jenis dan Sumber Data}

Jenis data dalam penelitian ini adalah data sekunder.Data tersebut berupa laporan keuangan tahunan 2011 hingga 2015 yang telah dipublikasi di website BUS terkait. Data pada penelitian ini merupakan panel data, karena dengan melibatkan banyak sampel pada tiap periodenya (cross section) dan melibatkan urutan waktu (time series). Sumber-sumber lain juga digunakan untuk mendukung penelitian ini seperti buku literatur, penelitian terdahulu, dan artikel dari internet.

\section{Populasi dan Sampel}

Populasi dalam penelitian ini berdasarkan website bank negara yang terdapat di kedua negara (Indonesia dan Malaysia), sebanyak 12 BUS Indonesia dan 17 BUS Malaysia. Untuk pemilihan sampel, menggunakan teknik purposive sampling, dengan kriteria BUS yang telah berdiri sejak tahun 2011, memiliki laporan keuangan yang dipublikasi dan memiliki waktu tutup buku satu kali. Sehinnga sampel penelitian ini sebanyak 11 BUS di Indonesia dan 16 BUS di Malaysia.

\section{Teknik Analisis}

\section{Regresi Data Panel}

Menurut Greene, (1993:481) dalam mengestimasi data panel terdapat tiga pendekatan yang biasa dilakukan, yaitu model OLS pooled, model fixed effect (FEM), model random effect (REM).

Untuk menentukan estimasi model regresi panel, dilakukan beberapa uji untuk memilih metode pendekatan estimasi yang sesuai. Yang pertama adalah uji chow yang digunakan untuk memilih antara metode CEM atau FEM.Pengambilan keputusan uji chow didasarkan dari nilai probabilitas, dimana jika $p$-value $<0,05$ maka penggunaan metode FEM lebih baik daripada metode CEM. Yang kedua adalah uji Hausman yang digunakan untuk memilih antara metode FEM atau REM. Pengambilan keputusan juga didasarkan dari nilai probabilitas, dimana jika $p$-value $<0,05$ maka metode FEM lebih baik dari REM (Ajijja, 2011:53).

\section{Uji Hipotesis}

Uji F

Uji $F$ bertujuan untuk mengetahui pengaruh semua variabel independen dalam satu model regresi terhadap variabel dependen. Pengujian dilakukan dengan menggunakan significance level $0,05(a=5 \%)$. Apabila signifikansi $<0,05$, maka $\mathrm{HO}$ ditolak atau secara simultan semua variabel independen berpengaruh 
Revida, et al/Jurnal Ekonomi Syariah Teori dan Terapan Vol. 4 No. 5 Mei 2017: 367-380; ANALISIS PENGARUH STRUKTUR PASAR DAN PERILAKU PASAR TERHADAP KINERJA PASAR PADA BANK UMUM SYARIAH DI INDONESIA DAN MALAYSIA TAHUN 2011-2015

secara signifikan terhadap variabel dependen.

Uji †

Uji † dilakukan untuk membuktikan apakah variabel independen secara individu

mempengaruhi variabeldependen. Pengujian dilakukan dengan menggunakan significance level 0,05 ( $a=5 \%$ ). Apabila signifikansi $<0,05$, maka HO ditolak atau secara parsial variabel independen berpengaruh secara signfikan terhadap variabel dependen. Sebaliknya, bila signifikansi > 0,05 maka HO diterima atau secara parsial variabel independen berpengaruh tidak signifikan terhadap variabel dependen

\section{Koefisien Determinasi}

Koefisien determinasi (R2) digunakan untuk mengukur persentase total variasi variabel dependen yang dapat dijelaskan oleh variabel independen dalam garis regresi.

\section{HASIL DAN PEMBAHASAN}

\section{Hasil Regresi Data Panel BUS Indonesia}

Tabel 1.

Hasil Pengujian Chow Test

\begin{tabular}{lrrr}
\hline \hline Effects Test & Statistic & d.f. & Prob. \\
\hline \hline Cross-section F & 5.511621 & $(10,41)$ & 0.0000 \\
Cross-section Chi-square & 46.859223 & 10 & 0.0000 \\
\hline
\end{tabular}

Sumber: Output Eviews 7

Berdasarkan tabel 1. diperoleh Pvaluesebesar 0,0000 lebih kecil dari a $(0,05)$ sehingga model digunakan yaitu Fixed Effect (FEM). Selanjutnya dilakukan Uji Hausman untuk mengetahui apakah metode FEM lebih baik dari REM.
Tabel 2.

Hasil Pengujian Hausman Test

\begin{tabular}{lrrr}
\hline \hline Test Summary & Chi-Sq. Statistic & Chi-Sq. d.f. & Prob. \\
\hline \hline Cross-section random & 11.128554 & 3 & 0.0111 \\
\hline
\end{tabular}

Sumber: Output Eviews 7

Berdasarkan tabel 2. diperoleh PvalueCross-section random sebesar 0,0111 yang berarti kecil dari a $(0,05)$ sehingga model Fixed Effect (FEM) merupakan model yang terbaik untuk digunakan. Berdasarkan hasil pemodelan, hasil estimasi model FEM dapat dilihat pada tabel 3.

Tabel 3.

Estimasi Regresi Data Panel dengan FEM

\begin{tabular}{|c|c|c|c|c|}
\hline \\
\hline \multicolumn{5}{|l|}{ Dependent Variable: } \\
\hline \multicolumn{5}{|c|}{ Method: Pooled Least Squares } \\
\hline \\
\hline \multirow{2}{*}{\multicolumn{5}{|c|}{$\begin{array}{l}\text { Sample: } 20112015 \\
\text { Included observations: } 5\end{array}$}} \\
\hline & & & & \\
\hline \multicolumn{5}{|c|}{ Cross-sections included: 11} \\
\hline \multicolumn{5}{|c|}{ Total pool (balanced) observations: 55} \\
\hline Variable & Coefficient & Std. Error & t-Statistic & Prob. \\
\hline c & 0.137359 & 0.017006 & 8.077068 & 0.0000 \\
\hline $\mathrm{IHH}$ ? & -0.586617 & 0.381910 & -1.536011 & 0.1322 \\
\hline SI? & 0.266852 & 0.247054 & 1.080136 & 0.2864 \\
\hline BOPO? & -0.156100 & 0.008843 & -17.65285 & 0.0000 \\
\hline \multicolumn{5}{|l|}{ Fixed Effects (Cross) } \\
\hline $1-C$ & -0.018571 & & & \\
\hline $2-C$ & 0.035548 & & & \\
\hline $3-\mathrm{C}$ & -0.005521 & & & \\
\hline $4-\mathrm{C}$ & 0.007632 & & & \\
\hline $5-\mathrm{C}$ & -0.007143 & & & \\
\hline $6-\mathrm{C}$ & -0.007650 & & & \\
\hline $7-\mathrm{C}$ & 0.009683 & & & \\
\hline $8--C$ & -0.010738 & & & \\
\hline $9-\mathrm{C}$ & 0.007951 & & & \\
\hline $10-\mathrm{C}$ & 0.006466 & & & \\
\hline $11-\mathrm{C}$ & -0.017657 & & & \\
\hline \multicolumn{5}{|c|}{ Effects Specification } \\
\hline \multicolumn{5}{|c|}{ Cross-section fixed (dummy variables) } \\
\hline R-squared & 0.892283 & \multicolumn{2}{|c|}{ Mean dependent var } & 0.007951 \\
\hline Adjusted R-squared & 0.858129 & \multicolumn{2}{|c|}{ S.D. dependent var } & 0.031965 \\
\hline S.E. of regression & 0.012040 & \multicolumn{2}{|c|}{ Akaike info criterion } & -5.785865 \\
\hline Sum squared resid & 0.005943 & \multicolumn{2}{|c|}{ Schwarz criterion } & -5.274907 \\
\hline Log likelihood & 173.1113 & & -5.588273 \\
\hline F-statistic & 26.12513 & & & 2.914534 \\
\hline Prob(F-statistic) & 0.000000 & \multicolumn{2}{|c|}{ Durbin-Watson stat } & \\
\hline
\end{tabular}

Sumber: Output Eviews 7

Berdasarkan hasil estimasi pada tabel 3. model yang terbentuk dari regresi linier berganda pada data panel adalah: $\mathrm{ROA}=0,137359-0,586617 \mathrm{IHH}+0,266852 \mathrm{Si}$ $-0,156100 \mathrm{BOPO}$ 
Revida, et al/Jurnal Ekonomi Syariah Teori dan Terapan Vol. 4 No. 5 Mei 2017: 367-380; ANALISIS PENGARUH STRUKTUR PASAR DAN PERILAKU PASAR TERHADAP KINERJA PASAR PADA BANK UMUM SYARIAH DI INDONESIA DAN MALAYSIA TAHUN 2011-2015

Berdasarkan persamaan diatas, penjelasannya adalah sebagai berikut:

1. Apabila seluruh variabel independen tidak mengalami perubahan atau konstan, maka ROA sebesar 0,137359

2. Apabila variabel $\mathrm{HH}$ mengalami peningkatan sebesar satu satuan sedangkan variabel independen lainnya dianggap konstan, maka ROA akan mengalami penurunan sebesar 0,586617 satuan.

3. Apabila variabel $\mathrm{Si}$ mengalami peningkatan sebesar satu satuan sedangkan variabel independen lainnya dianggap konstan, maka ROA akan mengalami peningkatan sebesar 0,266852 satuan.

4. Apabila variabel BOPO mengalami peningkatan sebesar satu satuan sedangkan variabel independen lainnya dianggap konstan, maka ROA akan mengalami penurunan sebesar 0.156100 satuan.

Hasil Uji $F$ pada tabel 3. menunjukan bahwa tingkat probabilitas (F-statistic) sebesar 0,000000 yang lebih kecil dari a $(0,05)$, sehingga dapat disimpulkan bahwa variabel $\mathrm{HH}$, Si dan BOPO secara simultan berpengaruh signifikan terhadap ROA pada BUS di Indonesia tahun 2011-2015.

Hasil Uji $†$ pada tabel 3. menunjukan bahwa dapat dijelaskan sebagai berikut:

1. Variabel $\mathrm{HH}$ memiliki probabilitas sebesar 0,1322 yang lebih besar dari a $(0,05)$, sehingga $\mathrm{H}_{0}$ diterima.
Kesimpulan yang dapat diperoleh adalah $\mathrm{IHH}$ tidak berpengaruh signifikan terhadap ROA.

2. Variabel Si memiliki tingkat probabilitas sebesar 0,2864 yang lebih besar dari a $(0,05)$, sehingga $\mathrm{H}_{\mathrm{O}}$ diterima. Kesimpulan yang dapat diperoleh adalah Si tidak berpengaruh signifikan terhadap ROA

3. Variabel BOPO memiliki tingkat probabilitas sebesar 0,0000 yang lebih kecil dari a $(0,05)$, sehingga $\mathrm{H}_{0}$ ditolak. Kesimpulan yang dapat diperoleh adalah BOPO berpengaruh signifikan terhadap ROA.

Berdasarkan tabel 3. diperoleh nilai koefisien determinasi $\left(R^{2}\right)$ sebesar 0,892283 . Angka tersebut menunjukkan bahwa variabel ROA BUS di Indonesia tahun 2011-2015 dapat dijelaskan oleh variabel $\mathrm{HH}$, pangsa pasar dan BOPO sebesar 89,2283\%, sedangkan sisanya yaitu $10,7717 \%$ dijelaskan oleh variabel lain yang tidak termasuk dalam penelitian ini.

\section{Hasil Regresi Data Panel BUS Malaysia}

Tabel 4.

Hasil Pengujian Chow Test

\begin{tabular}{lrrr}
\hline \hline Effects Test & Statistic & d.f. & Prob. \\
\hline \hline Cross-section $F$ & 0.981552 & $(15,61)$ & 0.4851 \\
Cross-section Chi-square & 17.296940 & 15 & 0.3014 \\
\hline \hline
\end{tabular}

Sumber: Output Eviews 7

Berdasarkan tabel 4. diperoleh nilai p-value sebesar 0,4851 lebih besar dari a $(0,05)$ sehingga dapat disimpulkan metode CEM merupakan model yang terbaik untuk digunakan bila dibandingkan dengan metode FEM, 
Revida, et al/Jurnal Ekonomi Syariah Teori dan Terapan Vol. 4 No. 5 Mei 2017: 367-380; ANALISIS PENGARUH STRUKTUR PASAR DAN PERILAKU PASAR TERHADAP KINERJA PASAR PADA BANK UMUM SYARIAH DI INDONESIA DAN MALAYSIA TAHUN 201 1-2015

sehingga tidak perlu dilakukan Uji

Hausman.

Tabel 5.

Estimasi Regresi Data Panel dengan CEM

Dependent Variable: ROA?

Method: Pooled Least Squares

Date: 07/08/16 Time: 17:01

Sample: 20112015

Included observations: 5

Cross-sections included: 16

Total pool (balanced) observations: 80

\begin{tabular}{crlrr}
\hline \hline \multicolumn{1}{c}{ Variable } & Coefficient & Std. Error & t-Statistic & Prob. \\
\hline \hline C & 0.019312 & 0.004919 & 3.925518 & 0.0002 \\
IHH? & -0.087447 & 0.336468 & -0.259898 & 0.7956 \\
SI? & 0.034897 & 0.053046 & 0.657857 & 0.5126 \\
BOPO? & -0.046206 & 0.012539 & -3.684922 & 0.0004 \\
\hline \hline R-squared & 0.236669 & Mean dependent var & 0.006928 \\
Adjusted R-squared & 0.206537 & S.D. dependent var & 0.011474 \\
S.E. of regression & 0.010221 & Akaike info criterion & -6.280118 \\
Sum squared resid & 0.007939 & Schwarz criterion & -6.161017 \\
Log likelihood & 255.2047 & Hannan-Quinn criter. & -6.232367 \\
F-statistic & 7.854532 & Durbin-Watson stat & 1.572037 \\
Prob(F-statistic) & 0.000124 & & & \\
\hline \hline
\end{tabular}

Sumber: Output Eviews 7

Berdasarkan hasil estimasi pada

tabel 5. model yang terbentuk dari regresi linier berganda pada data panel adalah:

$\mathrm{ROA}=0,019312-0,087447 \mathrm{IHH}+0,034897 \mathrm{Si}$

$$
-0,046206 \text { BOPO }
$$

Berdasarkan persamaan diatas maka penjelasannya adalah sebagai berikut:

1. Apabila seluruh variabel independen tidak mengalami perubahan atau konstan, maka ROA sebesar 0,019312

2. Apabila variabel $\mathrm{IHH}$ mengalami peningkatan sebesar satu satuan sedangkan variabel independen lainnya dianggap konstan, maka ROA akan mengalami penurunan sebesar 0,087447 satuan.

3. Apabila variabel $\mathrm{Si}$ mengalami peningkatan sebesar satu satuan sedangkan variabel independen lainnya dianggap konstan, maka ROA akan mengalami peningkatan sebesar 0,034897 satuan.
4. Apabila variabel BOPO mengalami peningkatan sebesar satu satuan sedangkan variabel independen lainnya dianggap konstan, maka ROA akan mengalami penurunan sebesar 0,046206 satuan.

Hasil Uji F pada tabel 5. dapat diketahui bahwa tingkat probabilitas (Fstatistic) sebesar 0,000124 yang lebih kecil dari a $(0,05)$, sehingga dapat disimpulkan bahwa variabel $\mathrm{IHH}$, Si dan BOPO secara simultan berpengaruh signifikan terhadap ROA pada BUS di Malaysia tahun 20112015.

Hasil Uji $†$ pada tabel 5.menunjukan maka pengujian terhadap hipotesis pengaruh masing-masing variabel independen terhadap variabel dependen dapat dijelaskan sebagai berikut:

1. Variabel $\mathbf{I H}$ memiliki tingkat probabilitas sebesar 0,7956 yang lebih besar dari a $(0,05)$, sehingga $\mathrm{H}_{0}$ diterima. Kesimpulan yang dapat diperoleh adalah $\mathrm{HH}$ tidak berpengaruh signifikan terhadap ROA.

2. Variabel Si memiliki tingkat probabilitas sebesar 0,5126 yang lebih besar dari a $(0,05)$, sehingga $\mathrm{H}_{0}$ diterima. Kesimpulan yang dapat diperoleh adalah Si tidak berpengaruh signifikan terhadap ROA.

3. Variabel BOPO memiliki tingkat probabilitas sebesar 0,0004 yang lebih kecil dari a $(0,05)$, sehingga $\mathrm{H}_{0}$ ditolak. Kesimpulan yang dapat diperoleh adalah BOPO berpengaruh signifikan terhadap ROA. 
Revida, et al/Jurnal Ekonomi Syariah Teori dan Terapan Vol. 4 No. 5 Mei 2017: 367-380; ANALISIS PENGARUH STRUKTUR PASAR DAN PERILAKU PASAR TERHADAP KINERJA PASAR PADA BANK UMUM SYARIAH DI INDONESIA DAN MALAYSIA TAHUN 2011-2015

Berdasarkan tabel 5. nilai koefisien determinasi $\left(R^{2}\right)$ sebesar 0,236669 . Angka tersebut menunjukkan bahwa variabel ROA bank umum syariah di Malaysia tahun 2011-2015 dapat dijelaskan oleh variabel $\mathrm{IHH}$, pangsa pasar dan BOPO sebesar 23,6669\%, sedangkan sisanya yaitu $76,33317 \%$ dijelaskan oleh variabel lain yang tidak termasuk dalam penelitian ini.

\section{Pembahasan}

\section{Pengaruh IHH Terhadap ROA Pada BUS di Indonesia dan Malaysia}

Hasil penelitian ini menunjukan variabel rasio kosentrasi pasar yang dihitung dengan menggunakan Indeks Herfindahl-Hirchman tidak berpengaruh signifikan terhadap Return on Asset pada BUSdi Indonesia maupun di Malaysia. Hal tersebut dapat dilihat dari nilai signifikansi yang dihasilkan, yaitu sebesar 0,1322 untuk hasil pada BUS di Indonesia dan sebesar 0,7956 untuk hasil pada BUS di Malaysia. Nilai signifikansi tersebut lebih besar dari 0,05 , sehingga $\mathrm{H}_{1}$ dan $\mathrm{H}_{4}$ ditolak. Dengan begitu, hasil penelitian ini menolak paradigma SCP yang menyatakan bahwa kosentrasi pasar dapat mempengaruhi profitabilitas perusahaan.

Berdasarkan hasil penghitungan $\mathrm{IHH}$, struktur pasar BUS di Indonesia tahun 2011 hingga 2015 cenderung bersifat oligopoli. Menurut Teguh (2010:48-52), dalam pasar oligopoli biasanya ditandai oleh hadirnya sejumlah perusahaan yang beroperasi, namun demikian sedikit diantara mereka yang dapat menguasai pasar. Sedangkan struktur pasar BUS di
Malaysia tahun 2011 hingga 2015 cenderung bersifat persaingan sempurna. Didalam struktur pasar persaingan sempurna terdapat banyak penjual, yang tidak satupun diantaranya dapat mempengaruhi harga dan output pasar (Teguh, 2010:30-31). Dapat disimpulkan bahwa jenis struktur pasar di kedua negara tersebut menunjukan bank umum syariah tidak memiliki derajat kosentrasi penguasaan pasar yang tinggi di dalam sebuah industri. Apabila tingkat kosentrasi rendah maka tingkat persaingan pada industru tersebut tinggi. Sehingga hal ini sejalan dengan hasil penelitian yang membuktikan bahwa kosentrasi pasar tidak berpengaruh signifikan terhadap profitabilitas.

Struktur pasar BUS di Malaysia yang cenderung bersifat persaingan sempurna dapat dikatakan sebagai struktur pasar yang Islami. Bukti kedekatannya adalah karakteristik struktur pasar persaingan sempurna yang mana terdapat kebebasan keluar masuk pasar, diantara penjual dan pembeli tidak ada asymmetric information, dan harga ditentukan oleh pasar hampir sama dengan karakteristik struktur pasar dalam Islam. Struktur pasar dalam Islam adalah pasar yang menciptakan tingkat harga yang adil, tidak merugikan pihak manapun, serta didasari atas prinsip kebebasan dalam melakukan kegiatan ekonomi. Hal ini sesuai dengan firman Allah yang tertulis dalam QS.An-Nisa' ayat 29 yang berbunyi: 
Revida, et al/Jurnal Ekonomi Syariah Teori dan Terapan Vol. 4 No. 5 Mei 2017: 367-380; ANALISIS PENGARUH STRUKTUR PASAR DAN PERILAKU PASAR TERHADAP KINERJA PASAR PADA BANK UMUM SYARIAH DI INDONESIA DAN MALAYSIA TAHUN 2011-2015

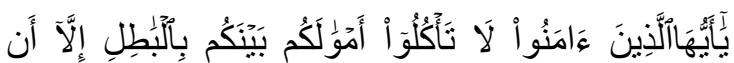

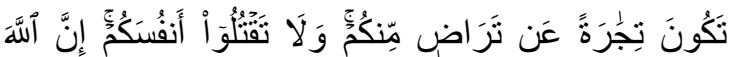

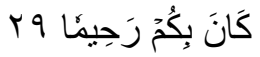

Yā ayyuhal-lażina āmanū lā ta'kulū amwālakum bainakum bil bātili illā an takūna tijāratan 'an tarādikum minkum, wa lā taqtulū anfusakum, innallāha kāna bikum rahimān

Artinya: Hai orang-orang yang beriman, janganlah kamu saling memakan harta sesamamu dengan jalan yang bathil, kecuali dengan jalan perniagaan yang berlaku suka sama-suka diantara kamu. Dan janganlah kamu membunuh dirimu; sesungguhnya Allah adalah Maya Penyayang kepadamu. (Departemen Agama Rl, 2012:75)

Dalam konsep Islam, struktur pasar yang cenderung bersifat oligopoli seperti struktur pasar BUS di Indonesia, tetap tidak dilarang keberadaannya, selama mereka tidak mengambil keuntungan di atas keuntungan normal (Karim, 2015:153). Oleh karena itu ajaran Islam melarang keras perbuatan yang sengaja menahan atau menimbun (hoarding) barang, terutama saat terjadi kelangkaan, dengan tujuan menaikkan harga di kemudian hari (ikhtikar) (P3El,

2014:333).Sebagaimanafirman

Allah dalamQS.Al-Hudayat 85 yang berbunyi:

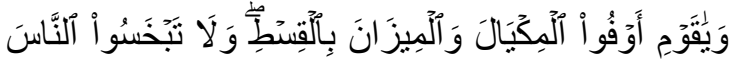

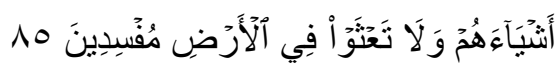

Wa yā qaumi auful mikyāla wal mizāna bil qisti wa lā tabkhasun nāsa asy-yā'ahum wa lā ta'sau fil ardi mufsidina

Artinya: Dan Syu'aib berkata: "Hai kaumku, cukupkanlah takaran dan timbangan dengan adil, dan janganlah kamu merugikan manusia terhadap hakhak mereka dan janganlah kamu membuat kejahatan di muka bumi dengan membuat kerusakan" (Departemen Agama Rl, 2012:207)

\section{Pengaruh Pangsa Pasar Terhadap ROA} Pada BUS di Indonesia dan Malaysia

Hasil penelitian menunjukan bahwa variabel pangsa pasar tidak berpengaruh signifikan terhadap ROA pada BUS di Indonesia dan Malaysia. Hal tersebut dapat dilihat dari nilai signifikansi yang dihasilkan, yaitu sebesar 0,2864 untuk hasil pada BUS di Indonesia dan sebesar 0,5126 untuk hasil pada BUS di Malaysia. Nilai signifikansi tersebut lebih besar dari 0,05 , sehingga $\mathrm{H}_{2}$ dan $\mathrm{H}_{5}$ ditolak. Dengan begitu, hasil penelitian ini menolak paradigma SCP yang menyatakan bahwa pangsa pasar dapat mempengaruhi profitabilitas perusahaan.

Secara umum, bank yang memiliki pangsa pasar pembiayaan yang tinggi akan mendapatkan keuntungan lebih dari peningkatan permintaan pembiayaan. Namun pada setiap transaksi pembiayaan yang dilakukan bank pasti mengandung risiko berupa risiko gagal bayar oleh debitur. Salah satu cara perhitungan risiko tersebut menggunakan rasio NPF. Menurut llusmawati dan Nuswantara (2014) menyatakan dampak dari NPF yang tidak wajar yaitu hilangnya kesempatan memperoleh pendapatan dari pembiayaan yang diberikan.

Dalam pemikiran Differentiation Hypothesis yang dijelaskan oleh Amalia dan Nasution (2007) menganggap bahwa pangsa pasar merupakan proksi dari hasil diferensiasi produk, dimana perusahaan yang melakukan diferensiasi produk dapat 
Revida, et al/Jurnal Ekonomi Syariah Teori dan Terapan Vol. 4 No. 5 Mei 2017: 367-380; ANALISIS PENGARUH STRUKTUR PASAR DAN PERILAKU PASAR TERHADAP KINERJA PASAR PADA BANK UMUM SYARIAH DI INDONESIA DAN MALAYSIA TAHUN 2011-2015

meningkatkan pangsa pasarnya dan kemudian perusahaan akan mendapat profit yang tinggi. Seperti yang sudah dijelaskan pada pembahasan sebelumnya, bahwa jenis struktur pasar di kedua negara tersebut menunjukan bahwa BUS tidak memiliki derajat kosentrasi penguasaan pasar yang tinggi di dalam sebuah industri. Artinya, bila dilihat secara global pangsa pasar bank umum syariah dikedua negara tersebut relatif kecil. Hal ini disebabkan karena baik di Indonesia maupun di Malaysia produk yang dipasarkan oleh antar BUS bersifat homogen. Sehingga dari tidak adanya produk yang terdiferensiasi maka bank umum syariah tidak dapat meningkatkan pangsa pasarnya, begitu pula dengan keuntungannya.

Pengaruh BOPO Terhadap ROA Pada BUS di Indonesia dan Malaysia

Hasil penelitian menunjukan bahwa variabel BOPO berpengaruh negatif signifikan terhadap ROA pada BUS di Indonesia dan Malaysia. Hal tersebut dapat dilihat dari nilai signifikansi yang dihasilkan, yaitu sebesar 0,0000 untuk hasil pada BUS di Indonesia dan sebesar 0,0004 untuk hasil pada BUS di Malaysia. Nilai signifikansi tersebut lebih kecil dari 0,05, sehingga $\mathrm{H}_{3}$ dan $\mathrm{H}_{6}$ diterima. Dengan begitu, hasil penelitian ini menerima paradigma SCP yang menyatakan bahwa perilaku perusahaan dapat mempengaruhi profitabilitasnya.

Berdasakan hasil penelitian, variabel BOPO dikedua negara tersebut menunjukan hasil yang siginifikan terhadap profitabilitas. Namun bila dilihat dari pertumbuhan nilai rasio BOPO dari tahun 2011 hingga 2015 pada BUS di Malaysia terlihat lebih efisien dari pada BUS di Indonesia dalam hal menjalankan kegiatan operasionalnya. Hal ini disebabkan di Indonesia pangsa pasar BUS hanya mencapai 5 persen, sedangkan di Malaysia pangsa pasar BUS sudah mencapai 20 persen. Sehingga untuk menaikkan pangsa pasarnya BUS di Indonesia lebih banyak mengeluarkan biaya untuk melakukan strategi dan inovasi agar tidak kalah bersaing dengan bank konvensional.

Menurut llusmawati dan Nuswantara (2014) menyatakan bahwa pencapaian tingkat efisiensi yang tinggi merupakan harapan masing-masing bank, karena dengan tercapainya efisiensi berati manajemen telah berhasil mendayagunakan sumber daya yang dimiliki secara efisien. Tingginya rasio BOPO menunjukan bahwa bank belum mampu menjalankan kegiatan operasionalnya secara efisien, sehingga berakibat turunnya profitabilitas. Semakin kecil rasio BOPO menunjukan semakin efisiennya bank dalam menjalankan kegiatan usahanya, sehingga kesempatan untuk memperoleh keuntungan yang lebih akan semakin tinggi.

\section{SIMPULAN}

Berdasarkan hasil penelitian dan juga pembahasan yang telah dilakukan mengenai hubungan Kosentrasi Pasar, Pangsa Pasar dan BOPO terhadap Return 
Revida, et al/Jurnal Ekonomi Syariah Teori dan Terapan Vol. 4 No. 5 Mei 2017: 367-380; ANALISIS PENGARUH STRUKTUR PASAR DAN PERILAKU PASAR TERHADAP KINERJA PASAR PADA BANK UMUM SYARIAH DI INDONESIA DAN MALAYSIA TAHUN 2011-2015

on Asset (ROA) maka simpulan yang dapat diambil adalah:

1. Variabel kosentrasi pasar yang dihitung dengan Indeks HerfindahlHirchman tidak berpengaruh signifikan terhadap profitabilitas yang diukur dengan ROA pada BUS di Indonesia tahun 2011-2015 pada signifikansi a 5\% dengan nilai t-statistic sebesar 1,53601 1 dan nilai signifikansi 0,1322.

2. Variabel pangsa pasar tidak berpengaruh signifikan terhadap profitabilitas yang diukur dengan ROA pada BUS di Indonesia tahun 20112015 pada signifikansi a 5\% dengan nilai t-statistic sebesar 1,080136 dan nilai signifikansi 0,2864.

3. Variabel BOPO berpengaruh negatif signifikan terhadap profitabilitas yang diukur dengan ROA pada BUS di Indonesia tahun 2011-2015 pada signifikansi a 5\% dengan nilai t-statistic sebesar $-17,65285$ dan nilai signifikansi 0,0000 .

4. Variabel kosentrasi pasar yang dihitung dengan Indeks HerfindahlHirchman tidak berpengaruh signifikan terhadap profitabilitas yang diukur dengan ROA pada BUS di Malaysia tahun 2011-2015 pada signifikansi a 5\% dengan nilai t-statistic sebesar 0,259898 dan nilai signifikansi 0,7956 .

5. Variabel pangsa pasar tidak berpengaruh signifikan terhadap profitabilitas yang diukur dengan ROA pada BUS di Malaysia tahun 2011-2015 pada signifikansi a $5 \%$ dengan nilai t- statistic sebesar 0,657857 dan nilai signifikansi 0,5126.

6. Variabel BOPO berpengaruh negatif signifikan terhadap profitabilitas yang diukur dengan ROA pada BUS di Malaysia tahun 2011-2015 pada signifikansi a 5\% dengan nilai t-statistic sebesar $-3,684922$ dan nilai signifikansi 0,0004 .

\section{DAFTAR PUSTAKA}

Ajija, Shochrul R dkk. 2011. Cara Cerdas Menguasai Eviews. Jakarta: Salemba Empat.

Amalia, Fitri dan Nasution, Mustafa Edwin. 2007. Perbandingan Profitabilitas Industri Perbankan Syariah dan Industri Perbankan Konvensional menggunakan Metode Struktur Kinerja dan Perilaku.Jurnal Ekonomi dan Pembangunan Indonesia. Vol VII, No. 02, Januari 2007, hlm. 159-179.

Antonio, Muhammad Syafi'i. 2001. Bank Syariah dari Teori ke Praktik. Jakarta: Tazkia Cendikia.

Bank Indonesia. Surat Edaran Bank Indonesia. (online), (http://www.bi.go.id, diakses 04 Maret 2016).

Deb, Ashis Taru dan K.V. Bhanu Murthy. 2008. Thoretical framework of Competition As Applied to Banking Industry. Delhi University. (online), (http://mpra.ub.unimurthymuenchen.de/7465, diakses pada 24 Juni 2016)

Departemen Agama RI. 2012. Al-Qur'an ku Arab, Latin dan Terjemahan. Jakarta: Lautan Lestari.

Greene, William H. 1993. Econometric Industri. New York: Macmillan Publishing Company.

llusmawati, Novia Cahya dan Dian Anita Nuswantara. 2014. Analisis Pengaruh Kekuatan Pasar dan Struktur Efisiensi Terhadap Return On Asset Bank. Jurnal IImu Manajemen. Vol 2 No. 4 Oktober 2014.

Jaya, Wihana Kirana. 2001. Ekonomi Industri Edisi 2. Yogyakarta: BPFEYOGYAKARTA. 
Karim, Adiwarman A. 2015. Bank Islam: Analisis Fiqih dan Keuangan. Jakarta: RajaGrafindo Persada.

Prasetyo, Hery dan Sony Sunaryo. 2015. The Branch Expansion and The Performance of Banks: The Case of Indonesia.Buletin Ekonomi Moneter dan Perbankan, Volume 18, Nomor 1, Juli 2015.

Pusat Pengkajian dan Pengembangan Ekonomi Islam (P3EI). 2014. Ekonomi Islam. Edisi 1 Cetakan ke-6. Jakarta: Rajawali Press.

Tallatov, Abra Puspa Ghani dan FX Sugiyanto. 2011. Analisis Struktur, Perilaku dan Kinerja Industri Perbankan di Indonesia Tahun 2003-2008. Tesis tidak diterbitkan. Semarang. Universitas Diponegoro.

Teguh, Muhammad. 2010. Ekonomi Industri. Jakarta: Rajawali Pers. 